\title{
Regeneration vs. Scarring: Did Evolution Get it Right?
}

\author{
Dale Feldman* \\ Department of Biomedical Engineering, University of Alabama at Birmingham, USA
}

Submission: February 14, 2018; Published: February 19, 2018

*Corresponding author: Dale Feldman, Department of Biomedical Engineering, University of Alabama at Birmingham, Birmingham, AL 35294 USA, Tel: 205934-8426; Fax: 205 975-4919; Email: dfeldman@uab.edu

\section{Opinion}

The fields of Regenerative Medicine and Tissue Engineering have exploded during the new millennium. In both, the goal is to restore function by either regenerating the original structure or by using an "engineered" replacement that is normally close to the original structure. Since we cannot yet build \$6M $(\$ 30 \mathrm{M}$ with inflation) men that function better than normal, re-creation of the original structure after an injury appears to be the best current option. There, however, are competing factors that would prevent this from being the optimal solution. The underlying question is: Does the loss of regenerative ability due to evolution produce the best clinical outcome?

Factors that affect the optimal treatment design include time of recovery, cost of treatment, technological feasibility, and commercializability (which includes ease of regulatory approval, profitability, and marketability as well as the other three factors). In essence this is an engineering design problem where all the commercializability factors plus the specific functional requirements need to be turned into "have to" and "would like to" design constraints (clinical performance and design requirements). Then solutions are judged based on the potential to meet all the "have to" design constraints as well as the most important "would like to" ones. This is hampered by our inability to accurately determine the potential of a given solution to meet a given design constraint and that virtually all clinical designs will have a failure rate (not meeting one or more design constraint(s) a certain percentage of the time).

In current clinical treatment the goal is to restore near normal function by combinations of repair, replacement, and rehabilitation. Although we have made progress in tissue engineering and regeneration we still cannot make tissue or organs that function like the original or induce stems cells to differentiate in a way to produce the right type of tissue/organ in 3-D. In most cases it is our inability to regenerate a functional 3-D vascular supply to help in the regeneration process and/ or maintain the tissue engineered or regenerated [1-3]. Again, even if we could regenerate a given tissue is that always the best solution? From a mechanical function perspective, regeneration is not normally a design constraint; unless esthetics is important (e.g. facial skin). Structural properties in many cases can come close for scarring, repair, or even replacement; strengthened with rehabilitation; and therefore meet the design constraint(s).

Through evolution (or God working through evolution) the scale has tipped toward scarring over regeneration in humans. Not entirely, however, since we can regenerate blood as well as other tissues and organs to a limited degree (e.g. bone, smooth muscle, liver, and epithelial tissue). It is not that we really lost it, since virtually all tissue is turned over at some rate (days to years depending on the tissue); most tissue has at least limited regenerative ability [2]; and we can increase the rate of regeneration with things like growth factors, stem cells, and electrical stimulation [3]. Further, babies up until about 6 months can regenerate an amputated finger and in utero surgery is essentially scarless $[2,3]$. So we have the machinery to regenerate, but scarring normally dominates; and even more so when healing time increases as in larger wounds, more inflammation, or less stem cells (as we get older or with certain diseases) $[2,3]$. So many strategies geared toward speeding up healing have the added benefit of reducing scarring [3].

So what has tipped the scales from regeneration to repair or scarring? From an evolutionary standpoint it is probably related to speed of recovery [4-7]; possibly why scarring increases as healing rate decreases. Why is scarring an evolutionary advantage? In part survival of the fittest" is more about those who can reproduce vs. that only the strongest survive who can reproduce [4-7]. Many animals can regenerate large parts of their body [5,7]. As the species and/or part gets larger it takes longer to regenerate and in most higher animals it iserves more as a defense mechanism [5]. For example, a lizard's tail comes off easily and will distract the prey, but requires nine months to regenerate (not seconds like in Spider Man) [5]. The African Spiny Mouse (skin comes off) and the axolotl salamander are other good examples of larger animals regenerating [5]. 
Although evolution may have kept regeneration as a defense mechanism to help in survival, for many larger species, the length of time for regeneration and the metabolic demand are too great in most cases [7]. It can make an animal easier prey or reduce the ability to reproduce [7]. To that end, many mammals will kill their young if they are injured or deformed and zoos often rescue babies who might be killed by their parents [8]. These evolutionary reasons don't seem as applicable today, for humans. We as a species have done a lot to weaken our gene pool by protecting and helping the weak among us to survive and reproduce (despite some eugenic efforts throughout history). For humans it is probably also to reduce infection; with scarring in many is in an effort to wall off an area infected or prone to infection $[3,4]$. This is still a good reason although less so as we have gotten better at wound healing and infection control. This can be seen in the advent of "moist wound healing" in burn patients to replace allowing the wound to dry out to reduce infection risk $[2,3]$.

Table 1: Biocompatibility hierarchy.

\begin{tabular}{|c|c|}
\hline Implant Response & Host Response \\
\hline Degradable & Regeneration \\
\hline Drug Delivery & Tissue Ingrowth \\
\hline Surface Active & Biointegration \\
\hline Inert & Inert \\
\hline
\end{tabular}

So as we are getting better at reducing the evolutionary reasons for scarring over regeneration and increasing the rate and amount of regenerative healing; we still need to ask is this always a good thing? From a design standpoint the best implants (top of the hierarchy) are ones that serve as a degradable regenerative scaffold (Table 1) [1] with the optimal ones having the regeneration rate controlled by the degradation rate of the implant. This is to prevent degradation from being a rate limiting step or too fast to reduce the scaffolding effect or compromise the mechanical function [1]. Although this is true from a performance point of view it is not necessarily true from a Commercializability point of view. The more complicated the tissue engineered product (growth factors, stem cells, biomimetic extracellular matrix scaffold, etc.) the more costly the product (including the treatment location and staff required), the more difficult the regulatory path, and the more time and cost it will be to develop as well as in some cases the more clinical risks.
Although the benefits to disadvantages tradeoffs are not easy to decide, it definitely means that the best performance is not always the best from a Commercializability standpoint.

The ramifications of this is regeneration is not always the best clinical design nor should it be the priority for funding in every case. The hierarchy idea suggests that we start where we are currently--normally close to the bottom (an implant that does not breakdown or stimulate any host response) and move up toward a degradable implant that serves as a scaffold that stimulates repair. Besides technological hurdles, the tradeoffs for Commercializability might also be too great to go all the way to the top of the hierarchy. From a research point of view it is OK to research for the best clinical performance, but also look toward a minimalist design: which factors can be removed and still meet the performance design constraints as well as still meet the Commercializability design constraints.

Evolution has caused selective loss of regenerative ability, based mostly on survival and reproduction; with the reasons today against regeneration different, but still present. We still have the innate ability to regenerate most tissue and organs as well as there are a number of good animal models (and many investigators) that are helping us to tip the scale more toward regeneration than scarring, when it is desired.

\section{References}

1. Feldman D, Czuwala P, Kelpke S, Pandit A, Wilson D (1995) A Biocompatibility Hierarchy: Justification for Biomaterial Enhanced Regeneration, Encyclopedic Handbook of Biomaterials and Bioengineering, Marcel Dekker, New York, USA, pp: 223-268.

2. Feldman D, (2018) Quantification and Modeling of Biological Processes for Tissue Engineering and Regenerative Medicine. Journal of Environment and Bio Research.

3. Feldman D, Barker T, Bowman J, Blum B, Kilpadi D, and Redden R (2000) Biomaterial Enhanced Regeneration for Skin Wounds, Biomaterials and Bioengineering Handbook, (Eds.), Wise D, Marcel D, New York, USA, pp: 807-842.

4. Atala A, Irvine DJ, Moses M, Shaunak S (2010) Wound Healing vs. Regeneration: Role of the Tissue Environment in Regenerative Medicine. MRS Bull 35(8).

5. (2018) 8 Regenerative animals changing the face of medicine.

6. (2017) Age and Effect on Wound Healing.

7. Bely AE, Nyberg KG (2009) Evolution of Animal Regeneration: Reemergence of a Field. Trends in Ecology \& Evolution. 25(3): 131-198.

8. Morrell V (2014) Why do Animals Sometimes Kill Their Babies? March 28. National.Geographic.com. 
This work is licensed under Creative Commons Attribution 4.0 License DOI: 10.19080/CTBEB.2018.12.555842
Your next submission with Juniper Publishers will reach you the below assets

- Quality Editorial service

- Swift Peer Review

- Reprints availability

- E-prints Service

- Manuscript Podcast for convenient understanding

- Global attainment for your research

- Manuscript accessibility in different formats (Pdf, E-pub, Full Text, Audio)

- Unceasing customer service

Track the below URL for one-step submission https://juniperpublishers.com/online-submission.php 